\title{
DISPERSAL PATTERN OF JUVENILES OF EMERGENT, CANOPY AND SHADE-TOLERANT TREE SPECIES ON FLOOD-PLANE FOREST AREA AT BERAU, EAST KALIMANTAN
}

\author{
Pola Penyebaran Anakan Jenis Pohon Emergent, Kanopi, dan Toleran Naungan pada \\ Hutan Dataran Rendah Luapan Banjir di Berau, Kalimantan Timur
}

Putu Oka Ngakan, Eiji Suzuki and Toshihiro Yamada

\begin{abstract}
.
Pola penyebaran anakan jenis pohon emergent (Shorea sp.), kanopi (Maduca malaccensis) dan toleran naungan (Aglaia tomentosa) telah diamati pada hutan dataran rendah luapan banjir di Berau, Kalimantan Timur. Hasil penelitian menunjukkan bahwa, penyebaran anakan ketiga jenis pohon tersebut sangat dipengaruhi oleh agen dispersal buah. Anakan Shorea sp., yang mana memiliki buah tipe samara, sebagian besar tersebar pada bagian Utara-Barat pohon induknya, mengikuti arah angin yang menerbangkan buahnya. Anakan dua jenis lainnya, yang mana buahnya yang bertipe berry sangat disukai oleh binatang mamalia, menyebar secara lebih merata. Struktur populasi anakan ketiga jenis tersebut menunjukkan kecenderungan yang berbeda. Shorea sp. menunjukkan struktur populasi berbentuk huruf J terbalik yang sangat tajam, sedangkan struktur populasi anakan dua jenis lainnya cenderung berbentuk garis horizontal. Perbedaan struktur populasi tersebut terkait dengan toleransi jenis-jenis tersebut terhadap naungan. Buah Shorea sp. yang jumlahnya melimpah segera berkecambah setelah jatuh, namun pertumbuhan anakan selanjutnya tertahan oleh naungan kanopy hutan yang sangat rapat.
\end{abstract}

Key words : Dispersal, Juvenil, Emergent, Canopy, Shade-tolerant

\section{INTRODUCTION}

Volumenous studies on the regeneration of some tree species, as well as the community of tropical rain forest had been reported (Djailany, 1986; Johns, 1987; Taguchi and Dalmacio, 1987; and Tukirin et al., 1987; Ngakan, 1999a; Ngakan, 1999b). However, only few of them intended to correlate the dispersal pattern of the juveniles to some environmental factors of habitat (Tarquebiau, 1986). Many environmental factors of habitat may impact simultaneously the dispersal of fruits or seeds in the field (Thohari and Santosa, 1986; Azuma, et al., 1994), the ability of the seeds to germinate and their further growth as well, which then determine the distribution pattern of the juveniles.

Fruits of some tree species maybe animal favorite, and therefore the distribution of their seeds will follow the dispersal of the animal that consume the fruits. Wind dispersed fruits or seeds may distribute in accordance with the direction of blowing wind. Fruits or seeds that are not animal favorite nor wind dispersed will fall under the canopy of their mother trees or be transported through stream flow by flood water when rain heavily fall.

This study is concerning the regeneration pattern of three species of tropical rain forest trees: Shorea sp. as an emergent tree species; Maduca malaccensis as a canopy species; and Aglaia tomentosa as a shade-tolerant species. Fruits of Shorea are wind dispersed, while those of two other species are animal favourite particularly monkey (for those still on the tree) or by wild pig or deer (for those have felt to the ground). However, fruits of Maduca malacensis are likely preferred by animal to those of Aglaia sp. This study had been carried on a one hectare $(100 \mathrm{~m} \times 100 \mathrm{~m})$ plot, which most part of it consists of flood plane area.

\section{STUDY SITE AND METHOD}

This study was conducted from August 3 to 19, 2002 in the concession area of HPH PT. Inhutani II, at Lebanan, Kabupaten Berau, East Kalimantan. A plot of $100 \mathrm{~m} \times 100 \mathrm{~m}$ (1 ha) was set on flood plane area. Few parts of the northern area of the plot consisted of gentle slope, which seems 


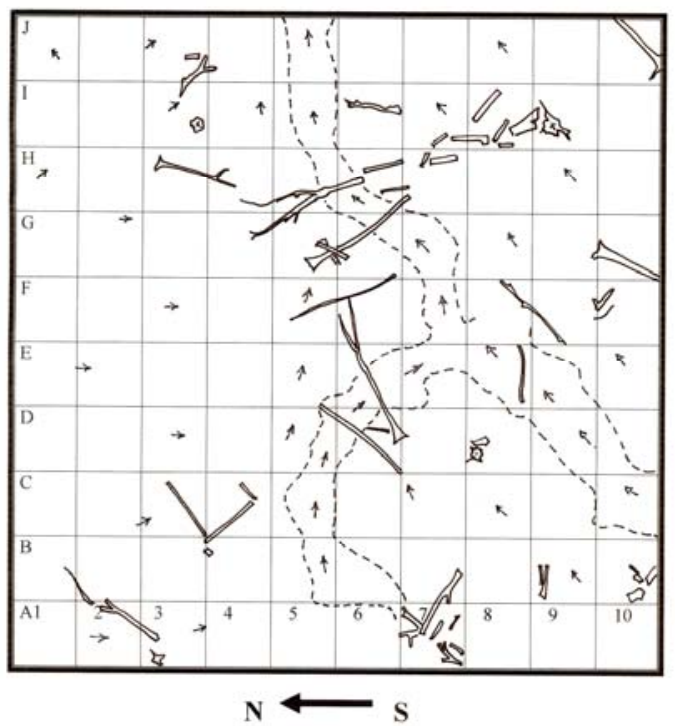

Figure 1. The view of the study plot. Arrow indicates the run off direction and dashed line indicates groove, which becomes stream during rainy peroid.

to be not subjected to flood even during heavy rain. The plot was divided into $10 \mathrm{~m} \times 10 \mathrm{~m}$ subplots (Sp), therefore in total there were 100 subplots (Fig. 1). Mother trees of the studied species coexisted in a subplot (Sp G4), which located at about the center of the main plot.

Due to their abundance in number and dense in distribution, juveniles of Shorea sp. and Aglaia tomentosa were observed in only 25 subplots (area in total: $0.25 \mathrm{ha}$ ) surrounding the subplot where mother trees of the studied species coexist. Juveniles of Maduca malaccensis were observed throughout the whole plot as their number were scarce. The number of individuals of each species was recorded separately for each subplot, and was distinguished into eight life stages as below:

(1) First stage (seedlings less than $50 \mathrm{~cm}$ in height),

(2) Second stage (seedlings between $50 \mathrm{~cm}$ and $130 \mathrm{~cm}$ in height),

(3) Third stage (saplings over $130 \mathrm{~cm}$ in height but less than $5 \mathrm{~cm}$ in diameter),

(4) Forth stage (poles between $5 \mathrm{~cm}$ and $10 \mathrm{~cm}$ in diameter),

(5) Fifth stage (young trees between $10 \mathrm{~cm}$ and $20 \mathrm{~cm}$ in diameter),

(6) Sixth stage (young trees between $20 \mathrm{~cm}$ and $30 \mathrm{~cm}$ in diameter),

(7) Seventh stage (young trees between $30 \mathrm{~cm}$ and $40 \mathrm{~cm}$ in diameter, for Aglaia tomentosa, trees under this size has begun flowering)

(8) Eighth stage (trees over $40 \mathrm{~cm}$ in diameter).

Individuals less than $50 \mathrm{~cm}$ in height were counted in only $1 / 4(5 \mathrm{~m} \times 5 \mathrm{~m})$ of each observed subplot. Individuals between $50 \mathrm{~cm}$ and $150 \mathrm{~cm}$ in height, as well as, those over $150 \mathrm{~cm}$ in height, but less than $5 \mathrm{~cm}$ in diameter were counted in 1/2 (5 $\mathrm{m} \times 10 \mathrm{~m}$ ) of each observed subplot. Individuals over $5 \mathrm{~cm}$ in diameter were counted in the whole of each observed subplot.

Since individuals of Maduca malaccensis were rare, they were observed throughout the whole plot (all the 100 subplots). In addition, spatial distribution pattern of this species was possibly mapped on a millimeter paper.

The stand where the plot was set had ever been logged during 1990, creating canopy gaps that influence the further stand regeneration. As mentioned earlier the plot was located on flood plane area. In order to show clearly the position of the logged over trees in the plot and the flow direction of water when flood, a map showing the condition of plot was drawn (Fig 1).

The effect of of light intencity on the population structure of each species, as well as the distribution pattern of their seedlings, was determined by recording the percentage of canopy cover of tree over $5 \mathrm{~m}$ in height. The percentage of canopy cover was determined by calculating the percentage of the ground area of each subplot that was penetrated by sunlight during the noon.

\section{RESULTS}

Stand where the plot located was relatively dense. The cover of forest canopy over $5 \mathrm{~m}$ from forest ground in average was more than $90 \%$. Whilst stem density of under-canopy trees (diameter less than $5 \mathrm{~cm}$ ) varies among subplots, ranging from 43 stems to 111 stems per subplot. Figure 2 shows the values of the canopy cover and stem density of the 25 observed subplots surrounding the mother trees of Shorea sp., Maduca malaccensis, and Aglaia tomentosa.

\section{Population Structure}

The three observed species showed different population structures, particularly at seedling and sapling stages (Fig. 3). The number of individuals of Shorea sp. at first seedling stage 


\begin{tabular}{|c|c|c|c|c|}
\hline $\begin{array}{l}\text { Sp: } \mathbf{~} 2 \\
C=98 \% \\
D=57\end{array}$ & $\begin{array}{l}\text { Sp: } 13 \\
C=98 \% \\
D=49\end{array}$ & $\begin{array}{l}\text { Sp: } 14 \\
C=82 \% \\
D=89\end{array}$ & $\begin{array}{l}\text { Sp: } 15 \\
C=98 \% \\
D=72\end{array}$ & $\begin{array}{l}\text { Sp: } 16 \\
C=90 \% \\
D=53\end{array}$ \\
\hline $\begin{array}{l}\text { Sp: } \mathbf{H 2} \\
C=95 \% \\
D=73\end{array}$ & $\begin{array}{l}\text { Sp: } \mathbf{H 3} \\
C=87 \% \\
D=86\end{array}$ & $\begin{array}{l}\text { Sp: } \mathbf{H 4} \\
C=96 \% \\
D=69\end{array}$ & $\begin{array}{l}\text { Sp: } \mathbf{H 5} \\
C=80 \% \\
D=44\end{array}$ & $\begin{array}{l}\text { Sp: H6 } \\
C=96 \% \\
D=66\end{array}$ \\
\hline $\begin{array}{l}\text { Sp: G2 } \\
C=95 \% \\
D=77\end{array}$ & $\begin{array}{l}\text { Sp: G3 } \\
C=94 \% \\
D=93\end{array}$ & $\begin{array}{l}\text { Sp: G4 } \\
C=98 \% \\
D=51\end{array}$ & $\begin{array}{l}\text { Sp: G5 } \\
C=94 \% \\
D=49\end{array}$ & $\begin{array}{l}\text { Sp: G6 } \\
C=92 \% \\
D=61\end{array}$ \\
\hline $\begin{array}{l}\text { Sp: F2 } \\
C=95 \% \\
D=67\end{array}$ & $\begin{array}{l}\text { Sp: F3 } \\
C=96 \% \\
D=56\end{array}$ & $\begin{array}{l}\text { Sp: F4 } \\
C=95 \% \\
D=66\end{array}$ & $\begin{array}{l}\text { Sp: F5 } \\
C=96 \\
D=58\end{array}$ & $\begin{array}{l}\text { Sp: F6 } \\
C=95 \% \\
D=54\end{array}$ \\
\hline $\begin{array}{l}\text { Sp: E2 } \\
C=98 \% \\
D=73\end{array}$ & $\begin{array}{l}\text { Sp: } E 3 \\
C=90 \% \\
D=111\end{array}$ & $\begin{array}{l}\text { Sp: } E 4 \\
C=96 \% \\
D=73\end{array}$ & $\begin{array}{l}\text { Sp: E5 } \\
C=98 \% \\
D=58\end{array}$ & $\begin{array}{l}\text { Sp: } E 6 \\
C=97 \% \\
D=43\end{array}$ \\
\hline
\end{tabular}

Figure 2. Matrix indicating the percentage of canopy cover (C) of each subplot and density (D) of stem less than $5 \mathrm{~cm}$ in diameter that exist inside each subplot.

(lower than $50 \mathrm{~cm}$ in height) was extremely abundant. However, it was obviously drop at the next higher stage (height between 50 and $130 \mathrm{~cm}$ ). It decreased continuously at sapling stage, until then there was no individual of Shorea sp. found at the pole and young tree stages.

In opposite to Shorea sp., there was no individual of Maduca malaccensis found both at first and second seedling stages, although observation was made throughout the whole 1 hectare plot. Some individuals were found at sapling and pole stages. A young tree of this species (diameter $32.44 \mathrm{~cm}$ ) was found growing closed to its mother tree.

Although the number of seedlings and sapling of Aglaia tomentosa decreased at higher live stage, the decreasing pattern was not as extreme as those of Shorea sp. However population structure of Aglaia tomentosa showed the same tendency as Shorea sp. for the absence of fourth and fifth live stages.

\section{Spatial Distribution Pattern of Seedlings}

As the number of seedlings of Shorea sp., and Aglaia tomentosa as well, are abundance, their spatial distribution pattern could not be mapped. Distribution pattern of these species was made in term of shadow diagram, in which the intensity of shade indicated the density of seedlings per subplot. Distribution pattern of the seedlings of Maduca malaccensis was possibly drawn as the number of individuals was not so abundant.

Figure 4 shows the distribution pattern of juveniles of Shorea sp. in the 25 observed subplots. Juveniles, particularly seedling less than $50 \mathrm{~cm}$ in height were not distributed evenly around their mother tree. Most seedlings were distributed at Northwestern side of their mother tree, and fewest at Southeastern side.

Distribution pattern of the juveniles of Maduca malaccensis (Figure 5), which were found only at third and fourth life stage, shows an opposite tendency to those of Shorea sp. Most of juveniles of Maduca malaccensis were distributed at Eastern side from their mother tree.

Although they were not as extremely abundant as juveniles of Shorea sp., juveniles of Aglaia tomentosa showed a similar distribution pattern to those of Shorea sp. Seedlings of Aglaia tomentosa were more abundance at the Western side of the mother tree (Figure 6), even though they still could be found in almost all subplots at the other directions of their mother tree.

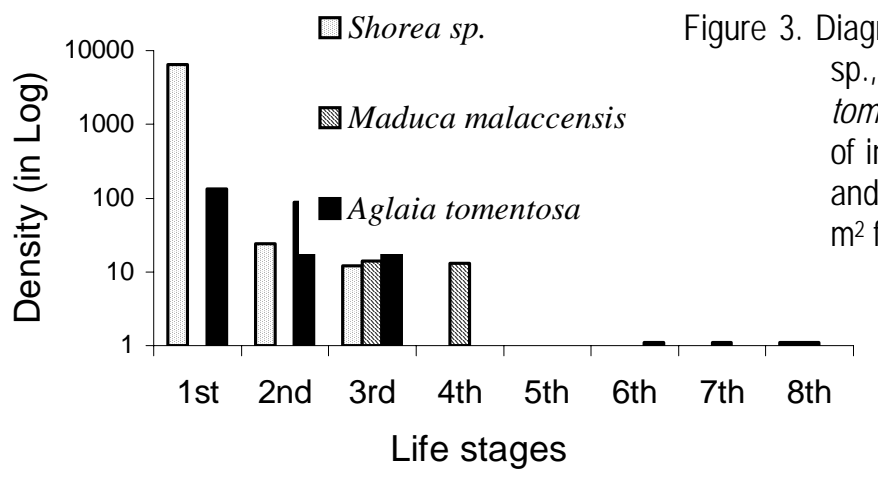




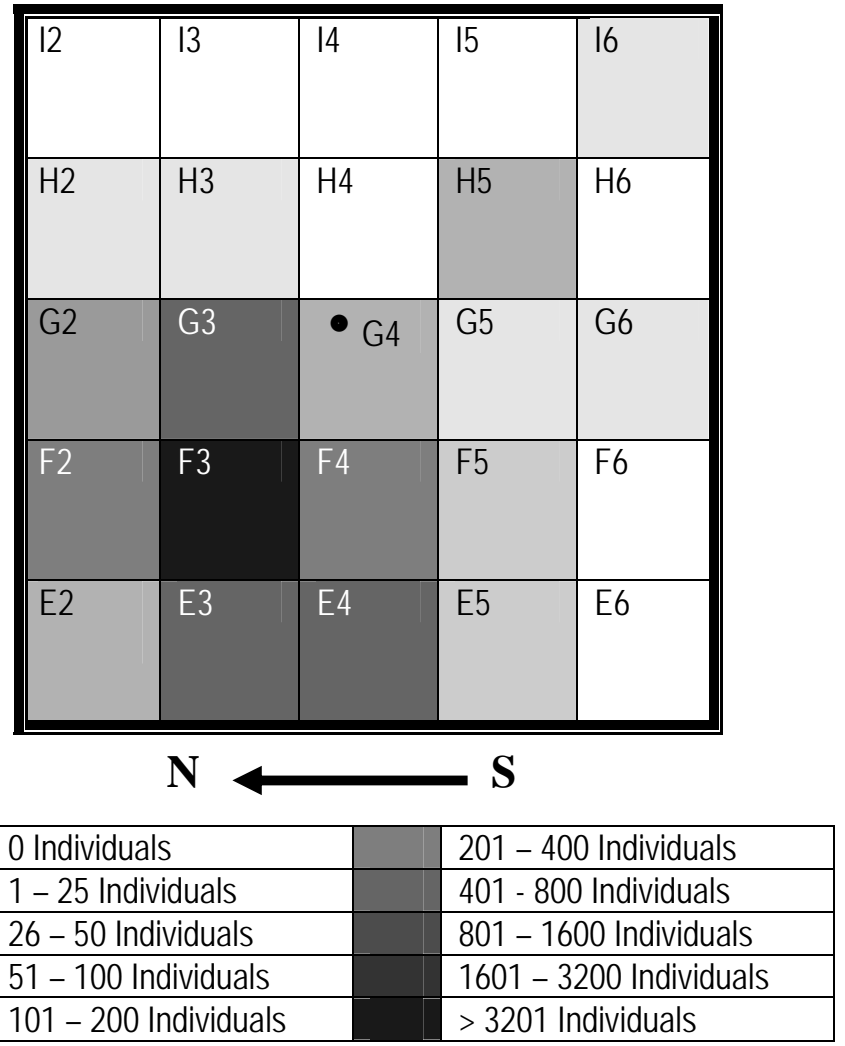

Figure 4. Distribution pattern of the juveniles of Shorea sp. The black circle in Sp G4 indicats the position of their mother tree.

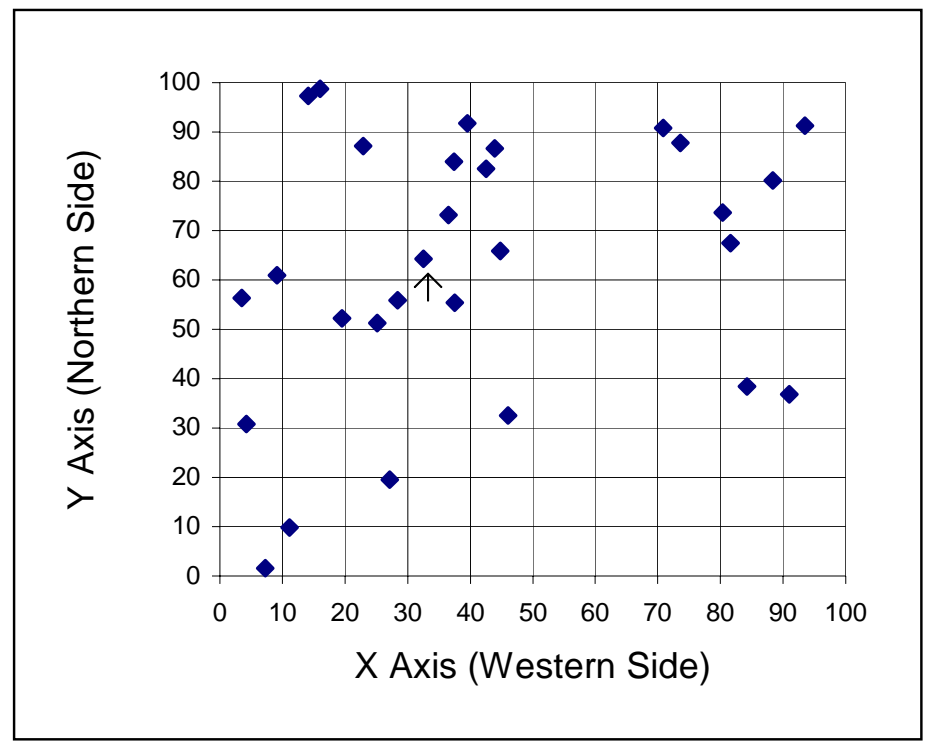

Figure 5. Distribution pattern of the juveniles of Maduca malaccensis. Grade lines on $Y$ axis indicates the number of subplot (Sp) from A (between 0 and 10) to J (between 90 to 100), while grade lines on $X$ axis indicates the number of Sp from 1 (between 0 and 10) to 10 (between 90 to 100). The Sp G4 is located in the connection of $Y$ axis between grade line 60-70 and $X$ axis between grade line 30-40. Individual pointed by arrow in Sp G4 is the mother tree. 


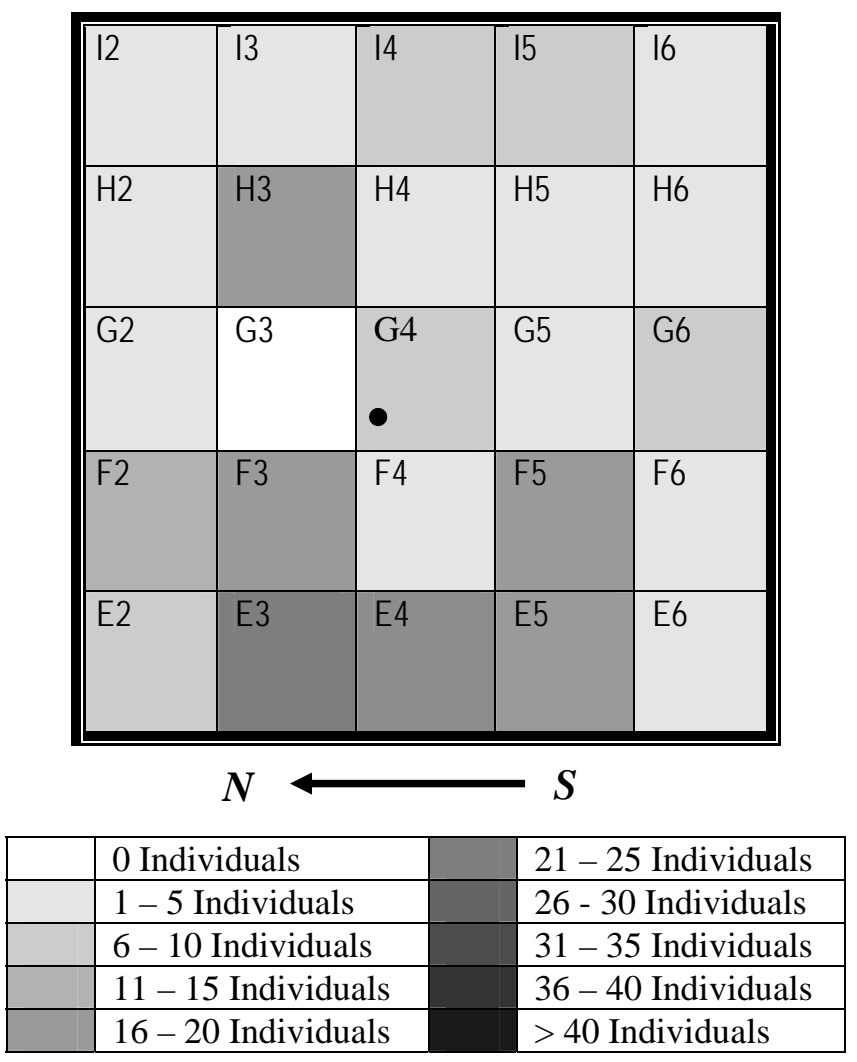

Figure 6. Distribution pattern of the juveniles of Aglaia tomentosa. The black circle in Sp G4 indicating the position of their mother tree.

\section{DISCUSSION}

\section{Population Structure}

A question appears that, while individuals of Shorea sp. and Aglaia tomentosa were found from seedling stages to sapling stage, why the seedling and sapling of Maduca malaccensis do not so? Although mass production of seed does not occur every year, the mother tree of each species should produce fruit annually. All the three species are not pioneer species, therefore their seeds should capable to germinate under the dense of canopy cover. However, the character of the seeds of each species will determine whether they will germinate immediately after fall or take some days or even weeks.

Seeds of Shorea sp. are only coated by a membrane-like thin endocarp. They usually germinate immediately after reaching ground and develop a rooting system. The period of seed dormancy is relatively short, often less than a week. The seeds usually die if they do not reach ground immediately after fall. Similar to the seeds of Shorea sp., the coat of Aglaia tomentosa seeds is also relatively thin. The seed may germinate immediately after fall and develop intensive rooting system.

As common characteristics of the sapota species, seeds of Maduca malaccensis are coated by a hard and slick endocarp. The period of dormancy of the Maduca's seeds is relatively longer than two other species. Although they also capable to germinate under forest canopy, they may need more light intensity for initiating germination than the seeds of those two other species. When rain heavily falls, the dormant seeds will easily be transported by stream flow or flood. The presence of many individuals at sapling and pole stages may be the individual that grew from the seed germination about twelve years ago (in 1990), when more canopy gaps were created due to the logging activity.

The absence of the individual of Shorea sp. and Aglaia tomentosa at the life stage of pole ( $\left.4^{\text {th }}\right)$ and young tree $\left(5^{\text {th }}\right)$ indicates that the abundant 
seedling from seed germination every year only possible to grow up until sapling stage. Although the seedlings and saplings are shade tolerant, further growth after sapling stage may become difficult due to competition for space. As indicated in the Fig. 2, stem density of tree less than $5 \mathrm{~cm}$ in diameter was considered relatively high.

\section{Spatial distribution}

Dispersal agents likely affect strongly the distribution pattern of each species. As previously mentioned, fruits of Shorea sp. are dispersed by wind. As being observed during this study, wind blew from Southeastern side of plot to Northwestern side of plot. This direction is precisely fitting with the spatial distribution of the seedlings of Shorea sp., which mostly abundant at Northwestern side of their mother tree.

In opposite to Shorea sp., juveniles of Maduca malaccensis were mostly distributed at the Eastern side of their mother tree. Fruits of Maduca malaccensis are animal favorite, and the seeds from the fruits that consumed by animal may be distributed far away outside the plot. Some seeds from fruits that are not consumed by animals will fall and remained under the canopy of mother tree. Fruits usually ripe during rainy season in order to make the germinate seed possible to grow and develop rooting system. It is highly possible that the seeds of Maduca malaccensis that did not germinate immediately after fall were transported by flood water that flow from Southwestern side to Eastern side of the plot (See the direction of stream and flood water flow indicated by arrow in Fig. 1). The previously discussed phenomena maybe one of the factors affecting the distribution pattern of Maduca's juveniles.

Similar to Maduca malaccensis, flood may affect the distribution pattern of the Aglaia's juveniles. However, more seedlings are still remain at Western side of their mother tree. The ground of the Western side of the Aglaia's mother tree was higher than that of Eastern side, therefore flood water would be deeper causing stronger flow at Eastern side. The occurrence of more seedlings remained at the Western side of the mother tree may be caused by the weaker impact of flood water at that side.

\section{REFERENCES}

Azuma, S., P. O. Ngakan, N. Wirawan. 1994. Seed dispersal by mammals and birds in burnt-over area of Kutai National Park. In: Early recovery process of Kutai ecosystem (S. Azuma and N. Wirawan, Eds.). Kyoto University Primate Research Institute. Pp: 79 - 82.

Djailani U. R. 1986. Natural regeneration of dipterocarp forest: The secondary forest types. In: Forest fegeneration in Southeast Asia. Biotrop Special Publication No. 25. Pp: 129 138.

Johns R. J. 1987. The natural regeneration of Anisoptera and Hopea in Papua New Guinea. In: Proceeding of the third round table conference on dipterocarps (A. J. G. H. Kostermans, Ed.). UNESCO. Jakarta. Pp: 213233.

Ngakan, P. O. 1999a. Recovery process of tropical rain forest eleven years after great fire in Kutai National Park, East Kalimantan. Proceeding $2^{\text {nd }}$ International Workshop on Forest Fire Control and Suppression Aspects. Bogor.

Ngakan P. O. 1999b. Do burnt tropical rain forest need rehabilitation? In: Impacts of fire and human activities on forest ecosystem in the tropics ( $H$. Suhartoyo and T. Toma, Eds.). PUSREHUT and JICA Special Publication. Pp: 429-439.

Taguchi, Y. and R. V. Dalmacio. 1987. Aid to natural regeneration experiment. In: Proceeding of the third round table conference on dipterocarps (A. J. G. H. Kostermans, Ed.). UNISCO. Jakarta. Pp: 235-240.

Tarquebiau E. 1986. Tropical rain forest regeneration patterns as recognized by laying down forest mosaic maps. In: Forest regeneration in Southeast Asia. Biotrop Special Publication No. 25. Bogor. Pp: 139150

Thohari, M. and Y. Santosa. 1986. A preliminary study on the role of civet (Paradoxurus hermaphroditus) in the natural regeneration of palm (Pinanga kulii and $P$. zavana) at Gunung Gede-Pangrango National Park, West Java. In: Forest regeneration in Southeast Asia. Biotrop Special Publication No. 25. Bogor. Pp: 151-153.

Tukirin P., R. Yusuf, S. S. Purwaningsih, R. Abdulhadi, K. Kartawinata. 1987. A preliminary note on gapsin lowland dipterocarp forest in Wanariset, East Kalimantan. In: Proceeding of 
the third round table conference on dipterocarps (A. J. G. H. Kostermans, Ed.). UNISCO. Jakarta. Pp: 241-253.

Diterima : 28 Desember 2005

Putu Oka Ngakan, Department of Forestry, Faculty of Agriculture and Forestry, University of Hasanudin,

Telp./Fax ++ 62411 453909, Makassar City 90245 Indonesia

E-mail : ngakan@indosat.net.id

Eiji Suzuki, Department of Earth and Environmental Science, Faculty of Science, Kagoshima University,

Kagoshima 890-0065 Japan

Toshihiro Yamada, Kumamoto Prefectural University,

Kumamoto City, Japan 